\title{
PENINGKATAN HASIL BELAJAR AGAMA BAGI SISWA BERKEMAMPUAN RENDAH MELALUI PENERAPAN MODEL COOPERATIVE TEAM GAMES TOURNAMENT
}

\author{
Husen $^{1, *)} \&$ Arif Widodo ${ }^{2)}$ \\ ${ }^{1)}$ SDN 1 Terong Tawah, Lombok Barat, Indonesia \\ ${ }^{2)}$ Universitas Mataram, Mataram, Indonesia \\ E-mail: husennata5@unram.ac.id
}

\begin{tabular}{|c|c|}
\hline ARTICLE INFO & ABSTRAK \\
\hline $\begin{array}{l}\text { Article history } \\
\text { Received: August 10, } 2020 \\
\text { Revised: August 12, } 2020 \\
\text { Accepted: August 14, } 2020 \\
\text { Kata Kunci: } \\
\text { hasil belajar agama, siswa } \\
\text { berkemampuan rendah, Team } \\
\text { Games Tournament }\end{array}$ & $\begin{array}{l}\text { Berdasarkan data di lapangan siswa kelas V di SDN } 4 \text { Bajur, Keacamatan } \\
\text { Labuapi, Kabupaten Lombok Barat memiliki kemampuan rendah dalam } \\
\text { mata pelajaran agama. Maka dari itu perlu dilakukan upaya tindakan untuk } \\
\text { meningkatkan kemampuan siswa dalam memahami pelajaran agama. } \\
\text { Tindakan yang dilakukan adalah menerapkan Model Cooperative Team } \\
\text { Games Tournament (TGT) dalam proses pembelajaran. Penelitian ini } \\
\text { didesain dalam bentuk penelitian tindakan kelas. Dalam penelitian ini } \\
\text { menggunakan tiga siklus. Pada masing-masing siklus terdiri dari empat } \\
\text { tahapan yaitu perencanaan, pelaksanaan tindakan, observasi dan refleksi. } \\
\text { Pemilihan subjek penelitian menggunakan teknik Purposive sampling } \\
\text { dengan alasan subjek yang dipilih harus sesuai dengan tujuan penelitian. } \\
\text { Subjek yang dipilih dalam penelitian ini aalah siswa kelas Vyang berjumlah } \\
\text { siswa 26. Siswa di kelas ini diplih karena memiliki kemampuan rendah } \\
\text { dalam mata pelajaran agama. Pengumpulan data menggunakan tes, } \\
\text { observasi dan angket siswa. Instrument yang digunakan antara lain soal tes, } \\
\text { lembar kerja siswa, lembar observasi dan lembar angket. Masalah utama } \\
\text { dalam penelitian ini adalah apakah penerapan model Cooperative Team } \\
\text { Games Tournament dapat meningkatkan hasil belajar siswa kelas V di SDN } \\
4 \text { Bajur? Tindakan dalam penelitian ini dianggap berhasil dengan indikator } \\
\text { tingkat ketuntasan klasikal lebih dari } 75 \% \text { dan terjadi kenaikan hasil belajar } \\
\text { pada siswa berkemampuan rendah. Hasil penelitian menunjukkan bahwa } \\
\text { setelah dilakukan tiga siklus terdapat peningkatan kemampuan klasikal. } \\
\text { Pada siklus pertama ketuntasan klasikal } 26 \% \text {, siklus kedua 62\% dan siklus } \\
\text { ketiga } 96 \% \text {. Prestasi belajar siswa berkemampuan rendah juga telah } \\
\text { mengalami peningkatan. Selama tiga kali siklus hanya satu siswa yang } \\
\text { dinyatakan tidak tuntas. Berdasarkan dua indikator tersebut dapat } \\
\text { disimpulkan bahwa penggunaan model TGT berhasil meningkatkan hasil } \\
\text { belajar siswa. }\end{array}$ \\
\hline
\end{tabular}

\section{A. PENDAHULUAN}

Mata pelajaran Agama merupakan salah satu mata pelajaran yang memegang peranan penting dalam membentuk karakter siswa. Pada mata pelajaran agama siswa tidak hanya dituntut untuk mempunyai kemampuan kognitif tetapi juga kemampuan afektif. Kemampuan kognitif dan afektif memiliki hubungan yang erat dengan karakter siswa. Pada dasarnya karakter dapat dibentuk melalui kebiasaan (Sobri, Nursaptini, Widodo, \& Sutisna, 2019). Hal 
Husen, H. Widodo, A (2020). Peningkatan Hasil Belajar...

ini sesuai dengan beberapa penelitian terdahulu pembiasaan Shalat berjamaah dapat membentuk akhlaq yang baik pada siswa (Rajab, 2019). Namun demikian karakter juga dapat dibentuk melalui proses pembelajaran, salah satunya melalui mata pelajaran agama. Berdasarkan UU Sisdiknas no 20 tahun 2003 salah satu tujuan pendidikan nasional adalah mengembangkan potensi peserta didik agar beriman dan bertakwa kepada Tuhan Yang Maha Esa (Mannan, 2016). Terdapat sebuah penelitian yang menyatakan bahwa dewasa ini nilai keagamaan perlahan mulai tergerus oleh budaya asing (Taufiqurrahman \& Nida, 2019). Salah satunya adalah budaya hedonistik, materialistik dan individualistik. Lahirnya manusia Indonesia yang karakter dan bermoral ditengah derasnya arus degradasi moral sangat dirindukan (Supraptiningrum \& Agustini, 2015). Terlebih lagi dalam menghadapi abad 21 pendidikan karakter harus ditingkatkan (Komara, 2018). Maka dari itu salah satu langkah konkrit dalam menyelamatkan karakter anak bangsa adalah dengan meningkatkan peran mata pelajaran agama di sekolah.

Pada hakikatnya kompetensi spiritual di dalam kurikulum 2013 telah dikembangkan pada kompetensi inti yang pertama (KI 1) (Widodo, 2020). Namun demikian bukan berarti mata pelajaran agama boleh dikesampingkan. Pelajaran agama harus ditingkatkan perannya baik dalam membentuk kemampuan kognitif maupun afektif. Hal ini dikarenakan tingkah laku seseorang tergantung apa yang ada di dalam otaknya (kognitif) dan apa yang ada di dalam hatinya (afektif). Akbar (2015) berpendapat bahwa orang yang berkarakter adalah orang yang dapat ngerti, ngrasa, dan nglakoni. Di dalam pendidikan agama seorang siswa ditanamkan pengetahuan dan akhlak yang baik sehingga dapat melahirkan perilaku yang baik juga. Agama dapat dijadikan sarana dalam membentuk sikap toleransi (Usman \& Widyanto, 2019). Selain itu dalam pelajaran agama juga mengandung nilai-nilai sosial (Imam \& Arini, 2019). Agama tidak hanya sekedar ritual, tetapi juga ada unsur kemanusiaan yang dijunjung tinggi (Saihu \& Aziz, 2020). Namun demikian memberikan pengetahuan agama kepada anak didik bukanlah perkara yang mudah. Pembelajaran agama membutuhkan persiapan khusus (Maftuhin \& Fuad, 2018). Terlebih lagi menanamkan pengetahuan kepada siswa yang memiliki keterbatasan ingatan. Melakukan identifikasi terhadap kemampuan masing-masing peserta didik sangat penting (Widodo, Haryati, Maulyda, Umar, \& Erfan, 2020). Hal ini dikarenakan sebagian besar konsep dalam pendidikan agama berupa hafalan. Terlebih lagi jika minat baca rendah pembelajaran yang banyak mengandung hafalan sulit dilakukan. Hal ini dikarenakan membaca adalah kunci utama bagi setiap pelajar agar mendapatkan hasil belajar yang baik (Widodo, Indraswasti, Erfan, Maulyda, \& Rahmatih, 2020). Maka dari itu tidak mengherankan jika siswa yang mempunyai daya ingat rendah atau berkemampuan belajar rendah memiliki hasil belajar 
yang kurang memuaskan. Permasalahan seperti inilah yang dihadapi guru agama di SDN 4 Bajur. Rata-rata siswa di sini memiliki daya ingat yang rendah terutama yang berada di kelas V. Maka dari itu guru agama berusaha melakukan perbaikan proses pembelajaran dengan melakukan sebuah tindakan. Tindakan yang dilakukan oleh guru agama dalam hal ini adalah dengan menerapkan Model Cooperative Team Games Tournament (TGT) dalam proses pembelajaran.

Penggunaan model pembelajaran memiliki hubungan yang erat dengan hasil belajar siswa. Hal ini berkaitan dengan motivasi yang ditimbulkan akibat penggunaan model pembelajaran tersebut. Menurut Erfan, Widodo, Umar, Radiusman, \& Ratu (2020) motivasi belajar dapat menghilangkan rasa bosan ketika belajar. Maka dari itu penggunaan Model Cooperative Team Games Tournament di dalam pembelajaran agama diharapkan dapat meningkatkan motivasi siswa dalam belajar, karena mata pelajaran yang banyak mengandung hafalan cenderung membosankan. Pemilihan model permainan tidak terlepas dari manfaat dari permainan tersebut. Pada sebuah penelitian disebutkan bahwa permainan yang mengandung unsur gerak memiliki dampak yang positif terhadap perkembangan psikologi anak (Nawangsari, 2016). Lain halnya dengan game online yang memiliki dampak buruk terhadap perkembangan anak (Jatmiko \& Abidin, 2017). Terdapat beberapa penelitian yang menyatakan bahwa permainan mengandung usnur karakter (Nur, 2013). Selain itu permainan dapat digunakan untuk meningkatkan kemampuan kognitif siswa, dalam hal ini adalah prestasi belajarnya (Saadah \& Hidayah, 2013). Maka dari itu dalam tindakan ini yang dipilih adalah TGT model permainan yang mengandung unsur gerak.

Terdapat beberapa penelitian terdahulu yang menyatakan efektifitas model TGT dalam meningkatkan hasil belajar siswa. Penelitian pertama dilakukan oleh Rahmawati \& Muqdamien (2016), namun penelitian tersebut dilakukan pada mata pelajaran Matematika. Hasil penelitiannya menunjukkan bahwa penggunaan model TGT terbukti efektif dalam meningkatkan hasil belajar matematika. Efektivitas penerapan model TGT juga dapat meningkatkat motivasi belajar agama. Hal ini sesuai dengan penelitian Hasan (2018) yang menyatakan minat belajar siswa dapat ditingkatkan melalui penerapan model TGT. Pada penelitian lain ditemukan juga bahwa penggunaan model TGT dapat meningkatkan hasil belajar siswa pada mata pelajaran agama di sekolah dasar (Muntahaya, 2017). Berdasarkan beberapa penelitian terdahulu di atas dapat dirumuskan permasalahan dalam penelitian ini yaitu apakah penerapan model Cooperative Team Games Tournament dapat meningkatkan hasil belajar siswa kelas V di SDN 4 Bajur? 


\section{B. METODE PENELITIAN}

Jenis penelitian yang digunakan adalah penelitian tindakan kelas. Langkah-langkah penelitian mengadopsi model Kurt Lewin yang terdiri dari planning, action, observing dan reflecting (Dwitagama \& Kusuma, 2010; Erfan \& Ratu, 2017). Tahap perencanaan meliputi identifikasi proses belajar mengajar, pencapaian KKM siswa, diskusi teman sejawat, penyusunan instrument penelitian, dan penentuan tindakan. Tahap tindakan terdiri dari penerapan metode TGT dalam pembelajaran dan evaluasi pembelajaran. Tahap observasi meliputi pengamatan terhadap aktivitas pembelajaran dengan menggunakan metode TGT, ketepatan langkah-langkah pembelajaran, kesesuaian alat evaluasi yang digunakan, analisis kesalahan penggunaan model pembelajaran, analisis solusi pemecahan masalah dan analisis ketercapain tujuan pembelajaran. Tahap refleksi dan evaluasi dilakukan dengan melakukan diskusi bersama teman sejawat, membahas hasil temuan, melakukan komparasi kemampuan akademik sebelum dan sesudah tindakan, dan perencanaan untuk tahap tindakan selanjutnya. Penelitian ini dilaksanakan pada bulan September 2018 hingga Maret 2019. Lokasi penelitian di SDN 4 Bajur, Keacamatan Labuapi, Kabupaten Lombok Barat. Subjek analisis dalam penelitian ini adalah siswa kelas V dengan jumlah 26 siswa. Penentuan subjek penelitian menggunakan tekbik Purposive sampling. Peneliti menentukan sampel dengan cara menetapkan ciri-ciri khusus yang sesuai dengan tujuan penelitian yaitu siswa yang berkemampuan rendah untuk ditingkatkan hasil belajarnya. Pengumpulan data menggunakan test, angket dan observasi. Test digunakan untuk mengetahui peningkatan hasil belajar kognitif siswa. Observasi digunakan untuk mengetahui aktivitas belajar siswa selama proses pembelajaran di kelas. Angket digunakan untuk mengetahui persepsi siswa tentang penggunaan model TGT dalam proses pembelajaran. Instrumen yang digunakan dalam penelitian ini terdiri dari soal test, LKS, lembar observasi afektif dan lembar observasi aktivitas serta lembar angket siswa. Analisis data mengadopsi model Miles dan Huberman dengan tahapan reduksi data, deskripsi data, penyajian data, verifikasi data dan pengambilan kesimpulan. Indikator keberhasilan tindakan dalam penelitian ini antara lain: ketuntasan klasikal harus lebih dari $75 \%$ dari keseluruhan siswa yang menjadi subjek penelitian berdasarkan standar ketuntasan minimal (KKM) yang telah ditetapkan serta terdapat peningkatan prestasi belajar bagi siswa berkemanpuan rendah.

\section{HASIL DAN PEMBAHASAN}

Penelitian ini berlangsung sebanyak tiga siklus. Masing-masing siklus terdiri dari tahap perencanaan, tindakan, diagnosa/observasi dan tahap refleksi dan evaluasi. Aturan permainan 
yang diterapkan pada model TGT sebagai berikut: 1) Siswa berkelompok dan duduk di bangku sesuai urutan di dalam kelompoknya mulai dari nomor urut 2. 2) Siswa pada urutan pertama berdiri didepan untuk siap-siap memulai turnamen. 3) Setiap siswa memiliki waktu sekitar 2 menit untuk mengerjakan setiap soal. 4) Setelah siswa pada urutan pertama selesai mengerjakan soal kemudian dilanjutkan siswa pada urutan kedua dan seterusnya sampai selesai. 5) Pada turnamen ini siswa duduk di bangkunya masing-masing dan soal yang akan diestafet sampai soal turnamen tersebut habis. 6) Tim yang hanya memiliki lima anggota, pada urutan soal keenam dilanjutkan masih oleh siswa urutan 5 setelah itu baru soal diestafet lagi ke depan. 7) Siswa yang tidak mengerjakan soal turnamen harus tetap duduk dibangku masingmasing dan dilarang membantu siswa lain yang sedang mengerjakan soal turnamen. 8) Siswa yang tidak sportif atau melanggar peraturan permainan akan didikualifikasi dari permainan.

Berdasarkan hasil analisis dan refleksi pada siklus pertama dapat diketahui bahwa nilai teringgi yang diperoleh siswa adalah 85 sedangkan nilai terendahnya adalah 35. Jumlah siswa yang dinyatakan lulus sebanyak 7 siswa dengan ketuntasan klasikal sebesar 26\%. Berikut ini dapat disajikan data pada siklus pertama.

Siklus I

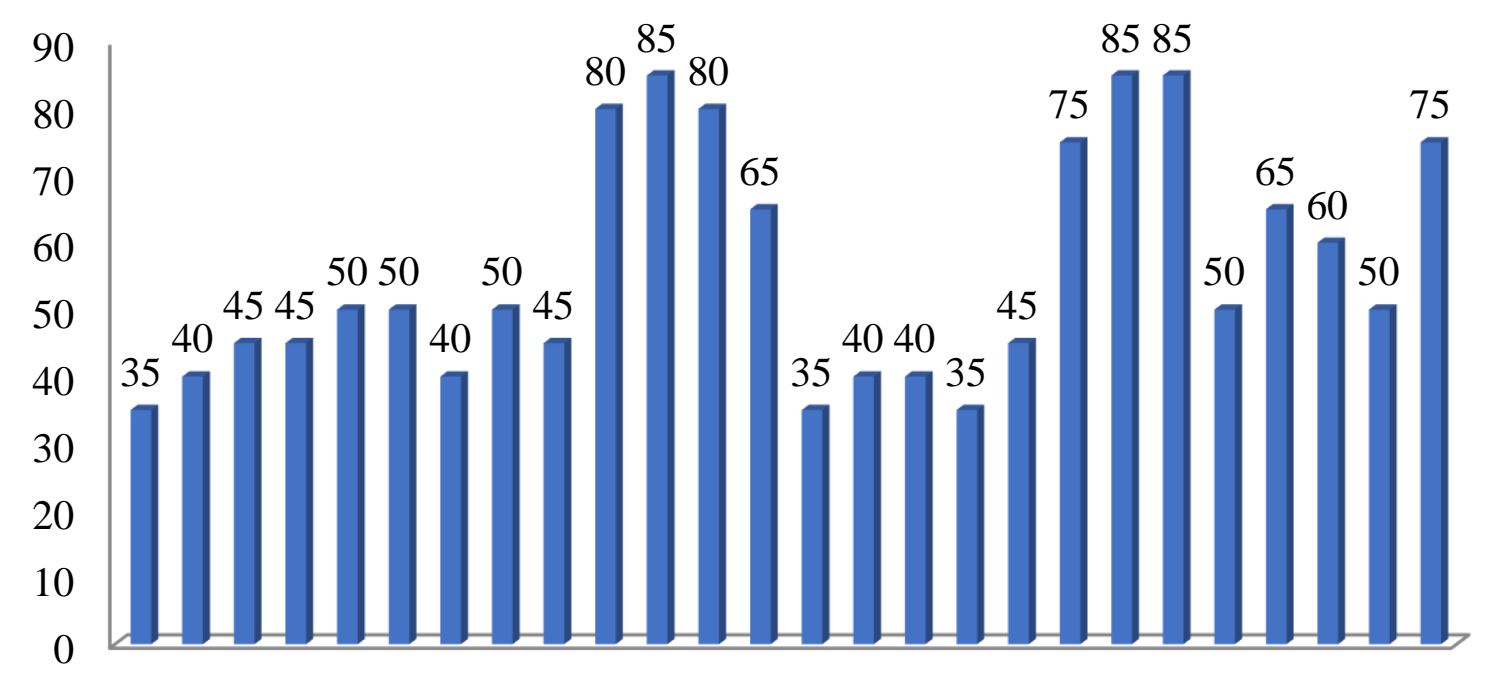

Gambar 1. Prestasi belajar siswa pada siklus I

Berdasarkan pada gambar 1 dapat diketahui bahwa nilai rata-rata kelas yang didapatkan siswa pada siklus pertama dalam aspek kognitif sebesar 54,81. Hal ini menunjukkan bahwa nilai rata-rata kelas masih berada di bawah KKM. Artinya adalah sebagian besar siswa belum melampaui standard KKM yang ditentukan. Berikut ini dapat disajikan persentase ketuntasan klasikal pada siklus 1 . 


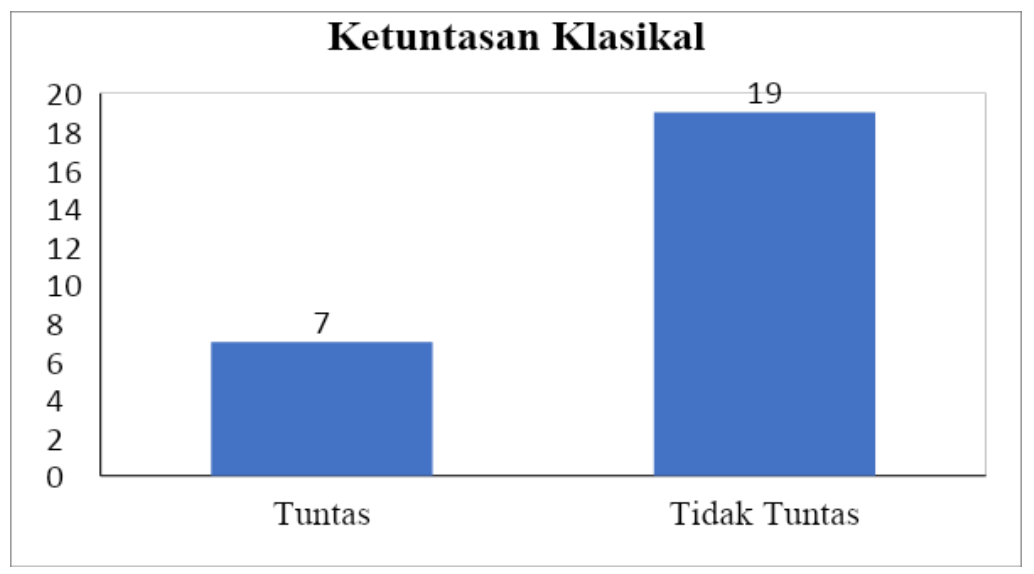

Gambar 2. Persentase ketuntasan klasikal siklus I

Berdasarkan pada gambar 2 dapat diketahui bahwa dari 26 siswa sebanyak 7 siswa dinyatakan lulus, sedangkan sebanyak 19 siswa dinyatakan belum lulus. Persentase kelulusan dpat dihitung dengan membandingkan jumlah siswa yang lulus dengan jumlah keseluruhan siswa di kelas tersebut. Hasilnya menunjukkan bahwa persentase kelulusan pada siklus pertama sebesar $26 \%$.

Berdasarkan hasil refleksi pada siklus pertama terdapat beberapa masalah sehingga hasil belajar siswa kurang maksimal. Pada siklus pertama masih banyak dijumpai siswa yang kurang memahami aturan pembelalajaran menggunakan model TGT. Maka dari itu penelitian dilanjutkan pada siklus II. Berikut ini dapat disajikan hasil belajar siswa pada siklus II.

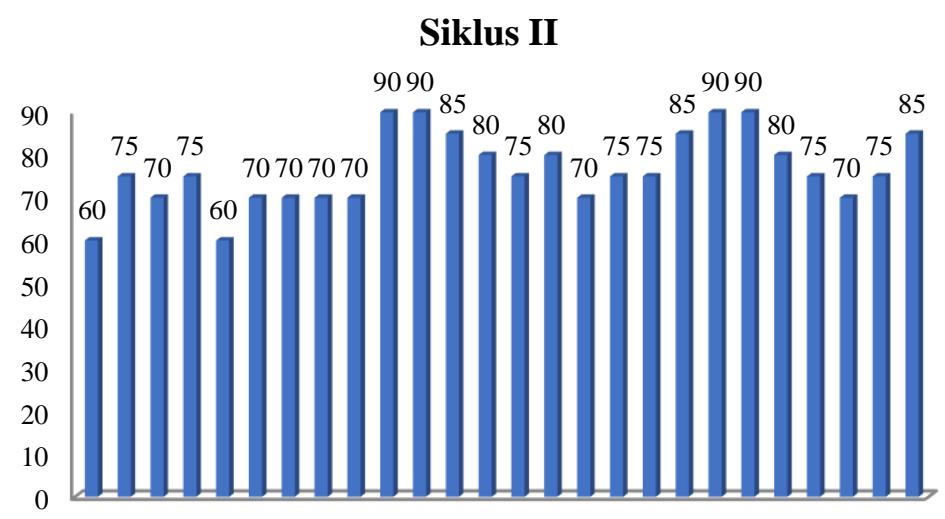

Gambar 3. Prestasi belajar siswa pada siklus II

Berdasarkan pada gambar 3 dapat diketahui bahwa Prestasi belajar siswa yang diperoleh siswa pada siklus II mengalami peningkatan. skor tertinggi yang didapatkan siswa dalam aspek kemampuan kognitif adalah 90 sedangkan skor terendahnya adalah 60. Nilai ratarata kemampuan kognitif pada siklus pertama sebesar 76.50. Ketuntasan klasikal juga mengalami peningkatan. berikut ini dapat disajikan persentase ketuntasan klasikal pada siklus II. 


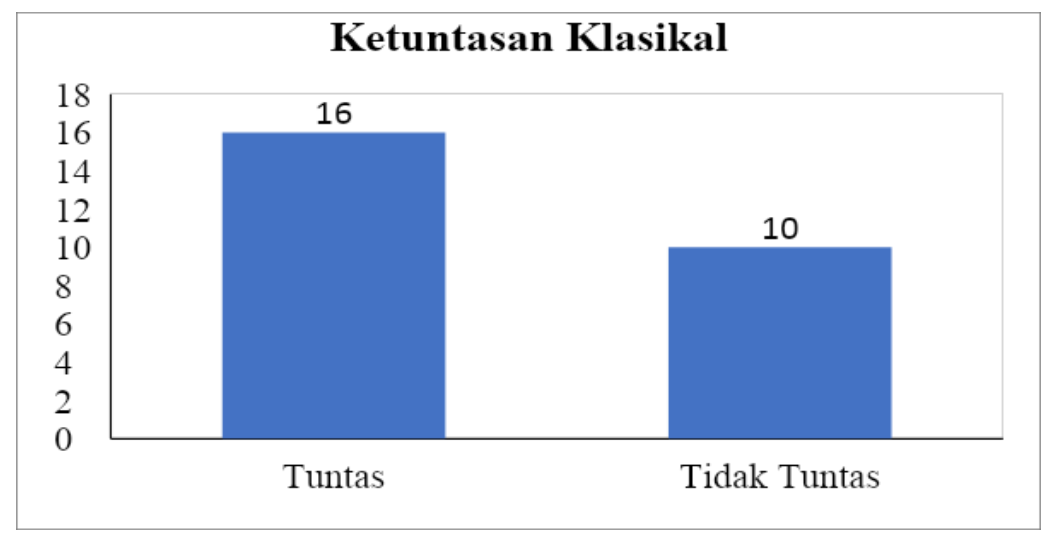

Gambar 4. Persentase ketuntasan klasikal siklus II

Berdasarkan gambar 4 dapat diketahui bahwa jumlah siswa yang telah tuntas sebanyak 16 siswa, sedangkan siswa yang belum tuntas sebanyak 10 siswa. Jika dihitung persentase ketuntasan klasikal kurang lebih sebesar $62 \%$. Hal ini dapat dipahami bahwa pada siklus II telah terjadi peningkatan ketuntasan klasikal jika dibandingkan dengan siklus I. Meskipun telah terjadi peningkatan namun belum sesuai dengan target yang ditentukan. Jumlah siswa yang belum paham aturan pembelajaran masih ada. Maka dari itu tindakan perlu dilanjutkan pada siklus III. Guru melakukan simulasi lagi agar siswa paham semua dengan aturan mainnya. Berikut ini dapat disajikan hasil belajar yang dilakukan pada siklus III.

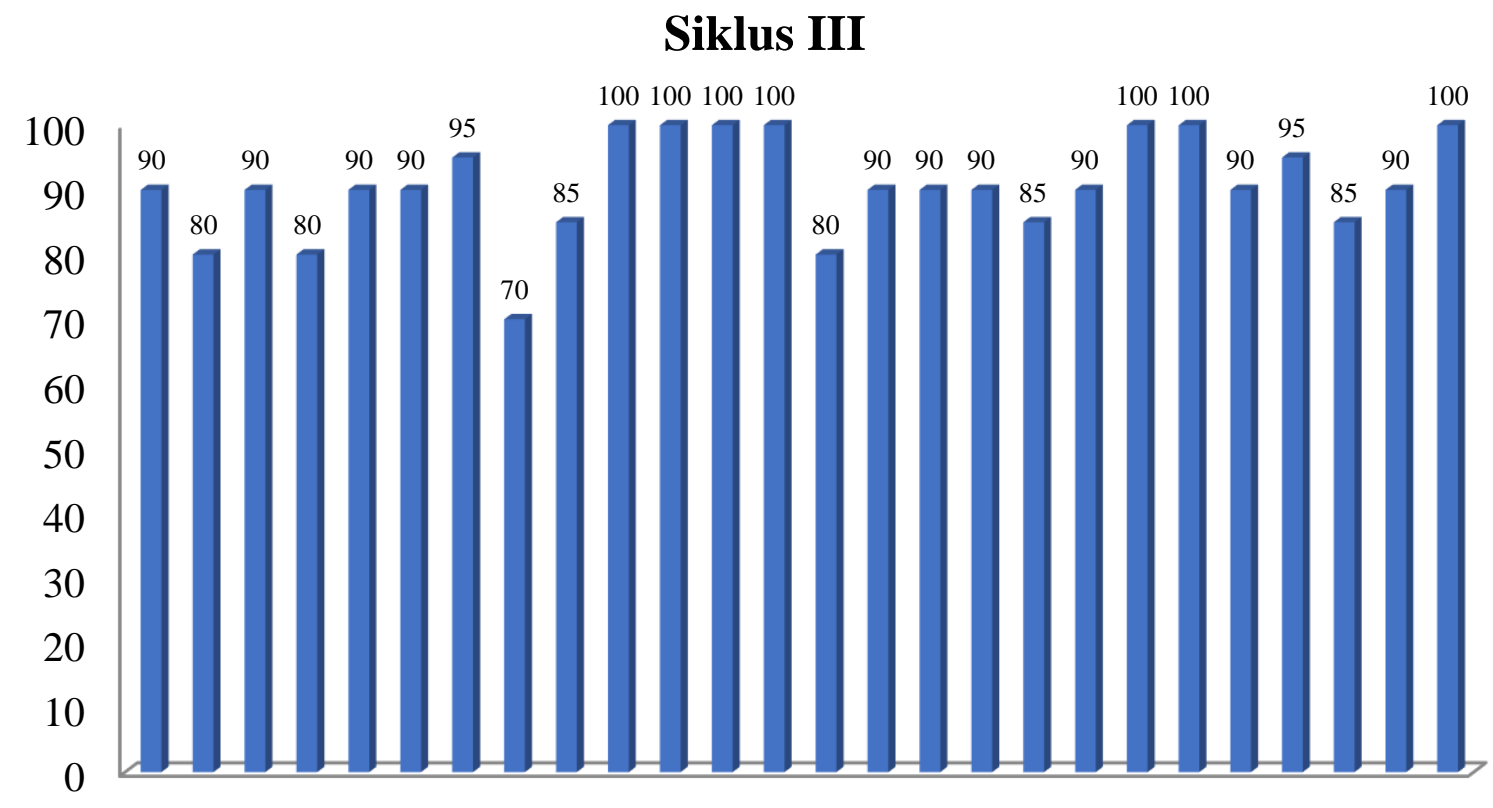

Gambar 5. Prestasi bealajar siswa pada siklus III

Berdasarkan gambar 5 dapat diketahui bahwa prestasi belajar siswa pada siklus ketiga mengalami peningkatan jika dibandingkan dengan dua siklus sebelumnya. Skor tertinggi pada ranah kognitif dapat mencapai skor maksimal yaitu 100 sedangkan skor terendahnya adalah 
70. Nilai rata-rata kelas yang diperoleh sebesar 90.58. Skor tertinggi pada ranah afektif adalah 95 sedangkan skor terendahnya adalah 85. Nilai rata-rata kelas sebesar 90. Ketuntasan klasikal pada siklus ketiga juga mengalami peningkatan. Berikut ini dapat disajikan persentase ketuntasan klasikal pada siklus III.

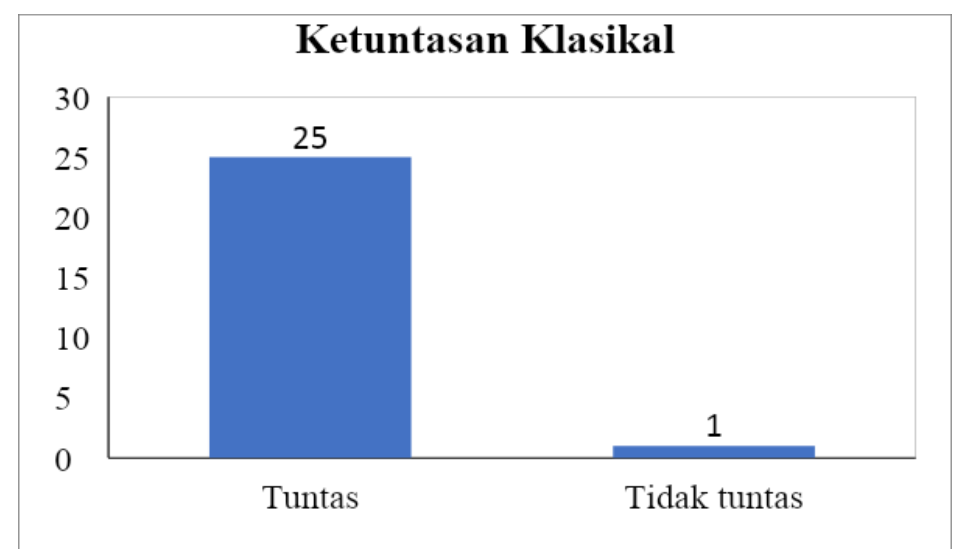

Gambar 6. Persentase ketuntasan klasikal siklus III

Berdasarkan gambar 6 dapat diketahui bahwa jumlah siswa yang telah tuntas pada siklus III sebanyak 25 siswa sedangkan yang tidak tuntas hanya 1siswa. Persentase ketuntasan kelas pada siklus III sebesar 96\%. Hal ini menujukkan bahwa sebagian besar siswa telah dinyatakan tuntas. Persentase ketuntasan pada siklus III telah melampaui ketuntasan klasikal yang ditentukan sehingga siklus dihentikan. Agar mempermudah dalam memahami peningkatan hasil belajar siswa pada masing-masing siklus dapat dilihat pada gambar 7 . Berdasarkan data yang disajikan pada gambar 7 dapat diketahui bahwa terdapat kenaikan persentase ketuntasan klasikal pada tiap siklus. Hal ini menunjukkan bahwa terdapat pengaruh antara tindakan yang diberikan terhadap hasil belajar siswa pada mata pelajaran agama.

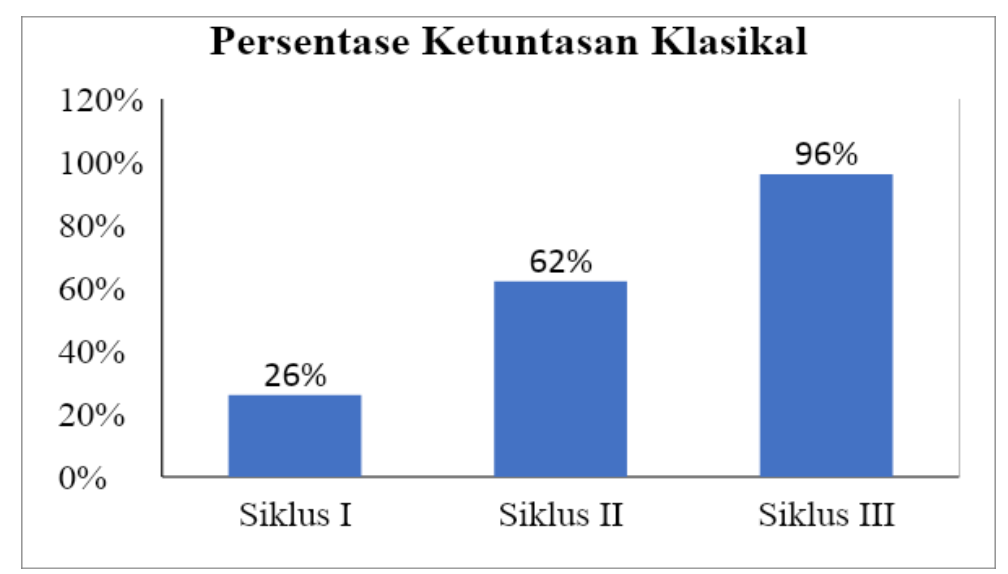

Gambar 7. Peningkatan ketuntasan klasikal 
Husen, H. Widodo, A (2020). Peningkatan Hasil Belajar...

Peningkatan hasil belajar siswa tidak hanya terjadi pada ranah kognitif saja, dalam aspek afektif juga terjadi peningkatan. Berikut ini dapat disajikan rata-rata kemampuan afektif siswa pada masing-masing siklus.

Tabel 1. Hasil belajar siswa pada ranah afektif

\begin{tabular}{llccc}
\hline No & \multicolumn{1}{c}{ Aspek yang diamati } & Siklus & Siklus & Siklus \\
& & I & II & III \\
\hline 1. & Siswa menunjukkan rasa tanggung jawab & 1 & 3 & 4 \\
2. & Siswa dapat berperilaku jujur dalam turnamen & 2 & 3 & 4 \\
3. & Siswa dapat melakukan kerjasama & 2 & 2 & 3 \\
4. & Siswa menunjukkan persaingan sehat selama turnamen & 2 & 3 & 4 \\
5. & Siswa berperan aktif dalam kegiatan pembelajaran & 2 & 3 & 4 \\
6. & Siswa dapat mempraktikkan aturan permainan TGT & 2 & 3 & 4 \\
7. & Siswa bersemangat dalam belajar & 2 & 3 & 4 \\
8. & Siswa dapat menghargai tim lawan & 2 & 3 & 4 \\
\hline & Jumlah skor & 15 & 23 & 31 \\
\hline & Skor Maksimal & 32 & 32 & 32 \\
\hline & Rata-rata kemampuan afektif & $47 \%$ & $72 \%$ & $97 \%$ \\
\hline
\end{tabular}

Berdasarkan Tabel 1 dapat diketahui bahwa hasil belajar siswa pada ranah afektif pada siklus pertama sebesar $47 \%$, pada siklus kedua sebesar $72 \%$ dan pada siklus ketiga sebesar $97 \%$.

Untuk memperkuat adanya pengaruh penggunaan model TGT dalam peningkatan hasil belajar siswa berikut ini disajikan data aktivitas belajar siswa.

Tabel 2. Data Aktivitas Belajar Siswa

\begin{tabular}{|c|c|c|c|c|c|c|c|}
\hline \multirow[b]{2}{*}{ No. } & \multirow[b]{2}{*}{ Aspek yang diamati } & \multicolumn{2}{|c|}{ Siklus I } & \multicolumn{2}{|c|}{ Siklus II } & \multicolumn{2}{|c|}{ Siklus III } \\
\hline & & $\begin{array}{l}\text { Jumlah } \\
\text { siswa }\end{array}$ & $\begin{array}{c}\text { Keaktifan } \\
(\%)\end{array}$ & $\begin{array}{c}\text { Jumlah } \\
\text { siswa }\end{array}$ & $\begin{array}{l}\text { Keaktifan } \\
(\%)\end{array}$ & $\begin{array}{l}\text { Jumlah } \\
\text { siswa }\end{array}$ & $\begin{array}{l}\text { Keaktifan } \\
(\%)\end{array}$ \\
\hline 1. & $\begin{array}{l}\text { Siswa serius } \\
\text { memperhatikan guru } \\
\text { selama pembelajaran }\end{array}$ & 12 & $46 \%$ & 17 & $65 \%$ & 23 & $88 \%$ \\
\hline 2. & $\begin{array}{l}\text { Siswa mendengarkan } \\
\text { penjelasan guru } \\
\text { tentang aturan } \\
\text { permainan TGT }\end{array}$ & 13 & $50 \%$ & 19 & $73 \%$ & 24 & $92 \%$ \\
\hline 3. & $\begin{array}{l}\text { Siswa mengerjakan } \\
\text { tugas dari guru } \\
\text { secara kelompok }\end{array}$ & 15 & $58 \%$ & 20 & $77 \%$ & 26 & $100 \%$ \\
\hline 4. & $\begin{array}{l}\text { Siswa mendengarkan } \\
\text { pendapat temannya }\end{array}$ & 16 & $62 \%$ & 19 & $73 \%$ & 25 & $96 \%$ \\
\hline
\end{tabular}


saat diskusi

kelompok

5. Siswa mengajukan pertanyaan kepada guru saat penjelasan materi

6. Siswa dapat mempraktikkan aturan permainan TGT

7. Siswa senang dan memiliki motivasi tinggi dalam pembelajaran TGT

8. Siswa tanggung jawab atas tugas 15 $58 \%$ 16

$62 \%$ yang diberikan kelompok

9. Siswa memberikan jawaban dalam tahap permainan (game)

10. Siswa Soprtif dalam Turnament yang dilakukan

\begin{tabular}{lrrrrrr}
\hline $\begin{array}{l}\text { Rata-rata keaktifan } \\
\text { kelas }\end{array}$ & 153 & $59 \%$ & 184 & $71 \%$ & 247 & $95 \%$ \\
\hline Rata-rata ideal & 260 & $100 \%$ & 260 & $100 \%$ & 260 & $100 \%$ \\
\hline Jumlah siswa & \multicolumn{2}{c}{26} & 26 & & 26 \\
\hline
\end{tabular}

Berdasarkan pada Tabel 1 dapat diketahui bahwa keaktifan belajar siswa dengan menggunakan model TGT terus meningkat dari siklus I sampai dengan siklus III. Pada siklus pertama aktivitas belajar siswa sebesar 59\%, siklus II sebesar 71\% dan siklus III sebesar 96\%. Hal ini menunjukkan bahwa penggunaan model TGT dapat meningkatkan partisipasi siswa dalam pembelajaran. Agar lebih mudah dalam memahami peningkatan aktivitas belajar siswa berikut disajikan perubahan aktivitas belajar siswa pada masing-masing siklus.

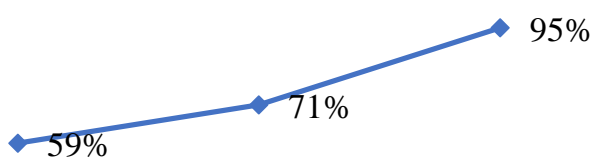

Siklus I Siklus II $\quad$ Siklus III

Gambar 8. Peningkatan aktivitas belajar siswa 
Untuk mengetahui respon dari siswa tentang model pembelajaran cooperative Teams Games Tournament ini, maka peneliti memberikan angket kepada siswa. Terdapat dua indikator angket yang diberikan kepada siswa. Angket pertama digunakan untuk mengetahui apakah siswa senang dengan penggunaan model pembelajaran TGT. Pada indikator pertama dari 26 siswa sebanyak 25 siswa mengatakan bahwa model TGT sangat menyenangkan, sedangkan 1 orang siswa mengatakan kurang menyenangkan. Setelah peneliti melakukan wawancara dengan siswa tersebut dia mengatakan sering dipaksa oleh temannya untuk menguasai materi yang belum dikuasainya. Angket kedua diberikan untuk mengetahui apakah dengan menggunakan model TGT siswa dapat lebih mudah memahami materi pelajaran. Berdasarkan angket yang kedua ini dapat diketahui bahwa semua siswa mengatakan bahwa dengan model TGT materi pelajaran dapat lebih cepat dikuasai.

Berdasarkan paparan data di atas dapat dipahami bahwa penggunaan model TGT dapat meningkatkan hasil belajar siswa pada mata pelajaran agama kelas V di SDN 4 Bajur. Hal ini sesuai dengan beberapa penelitian terdahulu yang menyatakan bahwa penggunaan model TGT efektif dalam meningkatkan hasil belajar siswa (Muntahaya, 2017). Penerapan model cooperative Teams Games tournament juga terbukti dapat meningkatkan prestasi belajar siswa yang berkemampuan rendah. Hal ini dapat terlihat dari siswa yang berkemampuan rendah hanya satu yang tidak tuntas. Selain penerapan model Cooperative Teams Games Tournament juga dapat meningkatkan semangat belajar siswa. Hal ini dapat terlihat berdasarkan hasil pengamatan dan angket siswa. Berdasarkan hasil angket semua siswa menyatakan sangat menyukai penerapan model TGT dalam pembelajaran agama. Hal ini sesuai dengan penelitian terdahulu yang menyatakan bahwa penggunaan model TGT dapat meningkatkan minat siswa dalam belajar (Hasan, 2018). Peningkatan minat belajar inilah yang dapat mendorong peningkatan hasil belajar siswa.

\section{SIMPULAN}

Berdasarkan hasil analisis data dan pembahasan dapat disimpulkan bahwa siklus pertama belum berhasil. Ketuntasan klasikal hanya $26 \%$ atau hanya 7 siswa yang tuntas dari 26 siswa yang menjadi subjek penelitian. Pada siklus kedua ketuntasan klasikal telah meningkat tetapi belum melampaui target yang ditentukan. Ketuntasan klasikal pada siklus kedua sebesar $62 \%$ sedangkan target ketuntasannya adalah $85 \%$. Memperhatikan hasil yang diperoleh pada siklus kedua belum mencapai tingkat ketuntasan, maka dilanjutkan ke siklus ketiga. Pada siklus ketiga (terakhir) dari 26 siswa kelas V SDN 4 Bajur yang telah tuntas belajarnya sebanyak 25 siswa, dan terdapat 1 siswa yang belum tuntas. Berdasarkan sebaran 
hasil dari masing-masing siklus mulai dari siklus pertama sampai dengan siklus ketiga, maka penelitian ini menunjukkan adanya peningkatan hasil belajar dengan tingkat ketuntasan, yaitu 96\%. Ketuntasan klasikal telah melebihi target ketuntasan yang ditetapkan sebelumnya yaitu 85\%. Penggunaan metode TGT juga dapat mneingkatkan motivasi belajar siswa. Hal ini dapat terbukti dengan angket siswa yang menunjukkan bahwa sebagian besar siswa senang menggunakan metode permainan dan dapat lebih cepat memahami materi pelajaran melalui permainan TGT. Secara keseluruhan pembelajaran dengan menerapkan model kooperatif teams games tournament pada siswa kelas V SDN 4 Bajur Kecamatan Labuapi Kabupaten Lombok Barat dapat dikatakan berhasil karena dapat meningkatkan hasil belajar siswa yang berkemampuan rendah dan ketuntasan klasikal melebihi target.

\section{DAFTAR PUSTAKA}

Akbar, S. (2015). Akbar, S. dkk. (2015). Pendidikan Karakter: Best Practices. Malang: Universitas Negeri Malang. Malang: Universitas Negeri Malang.

Dwitagama, D., \& Kusuma, W. (2010). Mengenal Penelitian Tindakan Kelas. Jakarta: PT Indeks.

Erfan, M., \& Ratu, T. (2017). Meningkatkan Minat Dan Hasil Belajar Mahasiswa Pada Perkuliahan Elektronika Dasar Melalui Digital Game-Based Learning. Meningkatkan Minat Dan Hasil Belajar Mahasiswa Pada Perkuliahan Elektronika Dasar Melalui Digital Game-Based Learning, 332-337. https://doi.org/S0962$\underline{8924(12) 00067-0}$

Erfan, M., Widodo, A., Umar, Radiusman, \& Ratu, T. (2020). Development of Android-Based Educational Game "Kata Fisika" for Elementary School Children on Concept of Force. Lectura: Jurnal Pendidikan, 11(1), 1-9. Retrieved from https://www.researchgate.net/profile/Muhammad_Erfan2/publication

Hasan. (2018). Pengaruh Model Pembelajaran Kooperatif Team Games Tournament Terhadap Minat Belajar Siswa Pada Mata Pelajaran Pendidikan Agama Islam (Kuasi Eksperimen di Kelas VIII C SMPN 4 Pandeglang) (UIN Sultan Maulana Hasanuddin Banten). from http://repository.uinbanten.ac.id/id/eprint/1842

Imam, H., \& Arini, A. (2019). Internalisasi Nilai-Nilai Pendidikan Agama Islam Dalam Upaya Membentuk Kepedulian Sosial Siswa MTs. Buq'atul Mubarokah Pakalongan Sampang Jawa Timur. Jurnal Pendidikan Islam Al-Ilmi, 2(2), 66-71. 
Jatmiko, G. A., \& Abidin, Z. (2017). The Comparison of Children Gadget Games And Hand On Activity Games To Their Socio-Emotional Skills. In L. Shanty (Ed.), Proceedings of Seminar and Workshop Educational Psychology (pp. 127-131). Bandung: Educational Psychology Program. School of Postgraduate Studies. Universitas Pendidikan Indonesia Editorial.

Komara, E. (2018). Penguatan Pendidikan Karakter dan Pembelajaran Abad 21. SIPATAHOENAN: South-East Asian Journal for Youth, Sports \& Health Education, 4(1), 17-26. Retrieved from www.journals.mindamas.com/index.php/sipatahoenan Maftuhin, M., \& Fuad, A. J. (2018). Pembelajaran Pendidikan Agama Islam Pada Anak Berkebutuhan Khusus. Journal An-Nafs: Kajian Penelitian Psikologi, 3(1), 76-90. https://doi.org/10.33367/psi.v3i1.502

Mannan, M. (2016). Pengembangan Perangkat Pembelajaran Berbasis Kearifan Lokal Untuk Mengembangkan Karakter Positif Siswa Sd. Jurnal Inovasi Dan Pembelajaran Fisika, 2(2), 141-146.

Muntahaya, A. R. (2017). Efektivitas metode pembelajaran TGT (Teams Games Tournament) dengan menggunakan media audio visual terhadap hasil belajar PAI materi pokok kisah sahabat nabi peserta didik kelas V SD Negeri Ngaliyan 01 Semarang tahun ajaran 2016/2017 (UIN Walisongo). Retrieved from http://eprints.walisongo.ac.id/id/eprint/7591

Nawangsari, G. (2016). Traditional games intervention effectiveness for children with internet addiction. (3), 729-733.

Nur, H. (2013). Membangun Karakter Anak Melalui Permainan Anak Tradisional. Jurnal Pendidikan Karakter, 3(1), 87-94. https://doi.org/10.21831/jpk.v0i1.1290

Rahmawati, \& Muqdamien, B. (2016). Peningkatan Hasil Belajar Matematika Pada Materi Operasi Hitung Perkalian Dan Pembagian Bilangan Pecahan dengan Menggunakan Model Team Games Tournament. Primary: Jurnal Keilmuan Dan Kependidikan $\begin{array}{llll}\text { Dasar, } & 8(1), & \text { Retrieved } & \text { from }\end{array}$ http://www.jurnal.uinbanten.ac.id/index.php/primary/article/view/150/152

Rajab. (2019). Implementasi Program Shalat Dhuha Dan Shalat Zuhur Berjamaah Dalam Pembentukan Akhlak Siswa (Studi Pada Sekolah SD Al Hira Permata Nadiah Medan). Jurnal ANSIRU PAI Vol., 3(2), 73-78. Retrieved from http://jurnal.uinsu.ac.id/index.php/ansiru/article/download/5852/2687 
Saadah, V., \& Hidayah, N. (2013). Pengaruh Permainan Scrabble Terhadap Peningkatan Kemampuan Membaca Anak Disleksia. Empathy, 1(1), 39-52.

Saihu, M. M., \& Aziz, A. (2020). Implementasi Metode Pendidikan Pluralisme Dalam Mata Pelajaran Pendidikan Agama Islam. Belajea; Jurnal Pendidikan Islam, 5(1), 131. https://doi.org/10.29240/belajea.v5i1.1037

Sobri, M., Nursaptini, N., Widodo, A., \& Sutisna, D. (2019). Pembentukan karakter disiplin siswa melalui kultur sekolah. Harmoni Sosial: Jurnal Pendidikan IPS, 6(1), 61-71. https://doi.org/10.21831/hsjpi.v6i1.26912

Supraptiningrum, S., \& Agustini, A. (2015). Membangun Karakter Siswa Melalui Budaya Sekolah Di Sekolah Dasar. Jurnal Pendidikan Karakter, (2), 219-228. https://doi.org/10.21831/jpk.v0i2.8625

Taufiqurrahman, \& Nida, N. H. (2019). Pendidikan karakter perilaku sosial anak usia sekolah dasar dalam keluarga di kota banjarmasin. Jurnal Tarbiyah: Jurnal Ilmiah Kependidikan, 8(1), 75-90.

Usman, M., \& Widyanto, A. (2019). Internalisasi Nilai-Nilai Toleransi dalam Pembelajaran Pendidikan Agama Islam di SMA Negeri 1 Lhokseumawe. DAYAH: Journal of Islamic Education, 2(1), 36. https://doi.org/10.22373/jie.v2i1.2939

Widodo, A. (2020). Proses Internalisasi nilai-nilai Karakter Madrasah Inklusi (Studi Deskriptif di MI NW Tanak Beak Lombok Barat). JURNAL PENDIDIKAN ISLAM AL-ILMI, 3(1), 27-38. https://doi.org/10.32529/al-ilmi.v3i1.562

Widodo, A., Haryati, L. F., Maulyda, M. A., Umar, \& Erfan, M. (2020). Proses identifikasi peserta didik berkebutuhan khusus di MI NW Tanak Beak Kabupaten Lombok Barat. Progres Pendidikan, 1(2), 63-71. Retrieved from http://prospek.unram.ac.id/index.php/PROSPEK/article/download/10/11

Widodo, A., Indraswasti, D., Erfan, M., Maulyda, M. A., \& Rahmatih, A. N. (2020). Profil minat baca mahasiswa baru PGSD Universitas Mataram. Premiere Educandum: Jurnal Pendidikan Dasar Dan Pembelajaran, 10(1), 34. https://doi.org/10.25273/pe.v10i1.5968 